\title{
Application of Scientific Guided Inquiry Assisted Video Analysis Tracker to Improve Science Generic Skills
}

\author{
Dens E. S. I. Asbanu \\ Physics Education Program STKIP SoE \& Badak Street, No. 5A SMK Negeri 1 SoE
}

\begin{abstract}
The study was done to identify the generic science skill improvement through guided scientific inquiry method video tracker analysis based. The method used in this study was quantitative pretest-posttest control group design. The samples of this were 52 students of the Physics Education Program of STKIP SoE. The instrument used in this study was a generic science skill test instrument on kinetic learning materials. The data analysis technique used was a t-test independent sample. The result of the study showed that students who learned guided scientific inquiry method video tracker analysis based were better than those who learned using the conventional method. This happened because the students were allowed to do the experiment that make the student freely understands generic science skill, thus making the learning process more interesting and meaningful. Therefore, it was suggested to use this method (guided scientific Inquiry method video tracker analysis based) in the process of learning in the classroom.
\end{abstract}

KEYWORDS: Generic Science; Kinematics; Mechanics; Tracker.

\section{INTRODUCTION}

The main problems faced by the students of senior high school and university in learning Physics are insufficiency of tools in the physics laboratory and the difficulty and access practice devices. However, the development of technology and information recently gives the possibility to create innovation in learning physics inside the classroom by using computers or laptops, cameras, and software trackers that are freely available and easy to access.

The application of video analysis trackers and cameras is effective in physics experiments, for example, analysis of the motion of falling objects in air and fluids [1][2], determine the acceleration due to gravity on the motion of the bullet [3], analysis of the conservation of mechanical energy in free-fall motion, pendulum motion, the motion of objects on an inclined plane, mass oscillations in springs [4], determination of the damping coefficient on weak damped vibrations [5], wave mechanics analysis [6], analysis of conservation of energy on a roller coaster [7], determine the moment of inertia of the fidget spinner [8]. However, there is still a lack of research on the implementation of video analysis in the physics learning process to improve students' generic science skills. The use of video analysis in physics experiments overcomes the inadequacy of experimental equipment, overcoming the limitations of observations that are difficult to distinguish with the eye. Video analysis tracker provides a simultaneous representation of abstract phenomena in quantitative data and [4][9].

The integration of technology video tracker analysis in learning physics is based on the requirements of 21-century learning that demand critical thinking skills, problem-solving, high order thinking skills, and visual literacy [10]. Based on this fact, the application of video analysis technology has to be used optimally in physics' learning. Using video tracker analysis in learning changes the learning approach which is teacher-center to be students center. Therefore, teachers are demanded to do innovation that can change conventional learning that makes the students more active in constructing knowledge. One of the learning innovations that is guided by scientific inquiry which student-center learning.

The guided science inquiry method is a learning method that encourages the students to use scientific procedures in solving problems. The steps of the guided inquiry video tracker based are formulating the problems, formulating a hypothesis, planning and doing the experiment, gathering and analyzing data, and communicating the experiment's result.

Some studies showed that the guided inquiry method was more effective than the conventional method in improving problem-solving skills [11] and physics' concept understanding [12]. But the problem was the difficulty of maintaining the devices to do the 


\section{International Journal of Current Science Research and Review}

ISSN: 2581-8341

Volume 04 Issue 12 December 2021

DOI: 10.47191/ijesrr/V4-i12-12, Impact Factor: 5.825

IJCSRR@ 2021

www.ijcsrr.org

observation. This caused the different results in which the conventional learning method was more effective and could be applied to physics learning. Conventional learning methods can only be effective in improving students' low-level thinking skills that as remembering and calculating.

The effort to improve students' high-level thinking skills is applying a learning method that orientates generic science skills [13]. According to Sudarmin, the prerequisite of high-order thinking skills is mastering skills in generic science. Generic science skill is the students' ability to think and act based on scientific understanding which is obtained from the learning process. Generic science skills is covering observation activity, awareness scale, symbolic language, logical inferential, the law of cause and effect, logical frame, logic consistency, creation, and abstraction [14][15]. This study aimed at identifying students' generic improvement through guided scientific inquiry video tracker analysis based.

\section{METHOD}

The research method used in this study was pretest-posttest quantitative control group design [16]. The samples in this study were students in the Physics Education Program of STKIP SoE which consisted of 54 students. The instrument used a generic science skill test on kinematics motion. The generic science skill test was valid by 0,71 reliability. The indicators of generic science skill tests were concept construction, order logic principle, logic inference, and mathematical modeling. The support instrument application in guided inquiry scientific through video tracker analysis-based mechanics learning materials video analysis based. Video analysis instrument that is used in physics experiment for example the kinematics motion of a ball which is thrown vertically the analyzed compared to the theory and measuring the gravity acceleration.

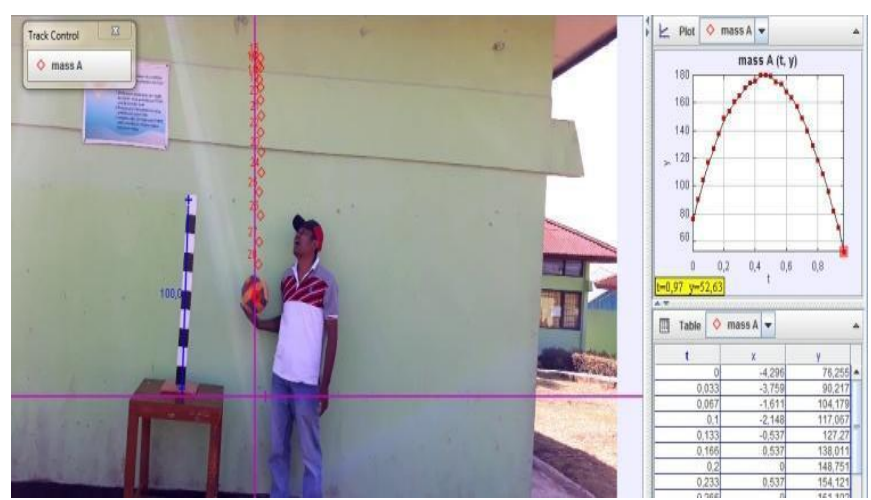

Figure 1: Vertical Ball Movement Analyzed using Tracker

In every experiment of physics, learning was equipped with good learning material. The guidance was given by the lecturer when the students found difficulties in using the learning materials. The data analysis technique used was an independent $\mathrm{t}$-test sample test using SPSS.

\section{RESULT AND DISCUSSIONS}

Table 1. The Description of generic science skill test result

\begin{tabular}{llll}
\hline Class & $\mathrm{N}$ & Mean & \\
\cline { 3 - 4 } & & Pretest & Posttest \\
\hline Experiment & 32 & 35,25 & 85 \\
Control & 22 & 33,26 & 52 \\
\hline
\end{tabular}

Table 1 showed that the pretest average grade (before treatment) of the experiment class was higher than the control class. However, based on the t-test result towards generic science skill grade in experiment and control class was gained the significance $>0,05$ meant that there was no significant difference generic science skill between students in control and experiment class before using guided inquiry scientific-based video tracker analysis. 


\section{International Journal of Current Science Research and Review}

ISSN: 2581-8341

Volume 04 Issue 12 December 2021

DOI: 10.47191/ijesrr/V4-i12-12, Impact Factor: 5.825

Table 2. t-test result of the experimental and control class.

\begin{tabular}{llllll}
\hline \multirow{2}{*}{ Class } & $\mathrm{N}$ & \multicolumn{1}{l}{$\mathrm{t}_{\text {test }}$} & \multirow{2}{*}{ df } & Sig \\
\cline { 3 - 4 } & & Pre & Post & & \\
\hline Experiment & 32 & 0,673 & 9,864 & 52 & 0,472 \\
Control & 22 & & & & 0,000 \\
\hline
\end{tabular}

The post-test result in Table 2 showed that the grade of the experiment class was higher than the control class (after treatment). The Independent t-test sample in Figure 2 showed the significance $<0,000$ meant that there was a significant difference in generic science skills after being treated using guided scientific inquiry-based video tracker analysis. The observation result on generic science skill indicators on concept construction, order logic principle, logic inference, mathematics model was shown in Figure 3. Figure 3 showed that generic science skill in the experiment class was higher than the control class on concept construction, basic logic principle, logic inference, and mathematics modeling aspect. Guided inquiry scientific method generally improves the students' generic science skill because, in this phase, the students were allowed to experiment with the main learning problem which was given by the lecturer.

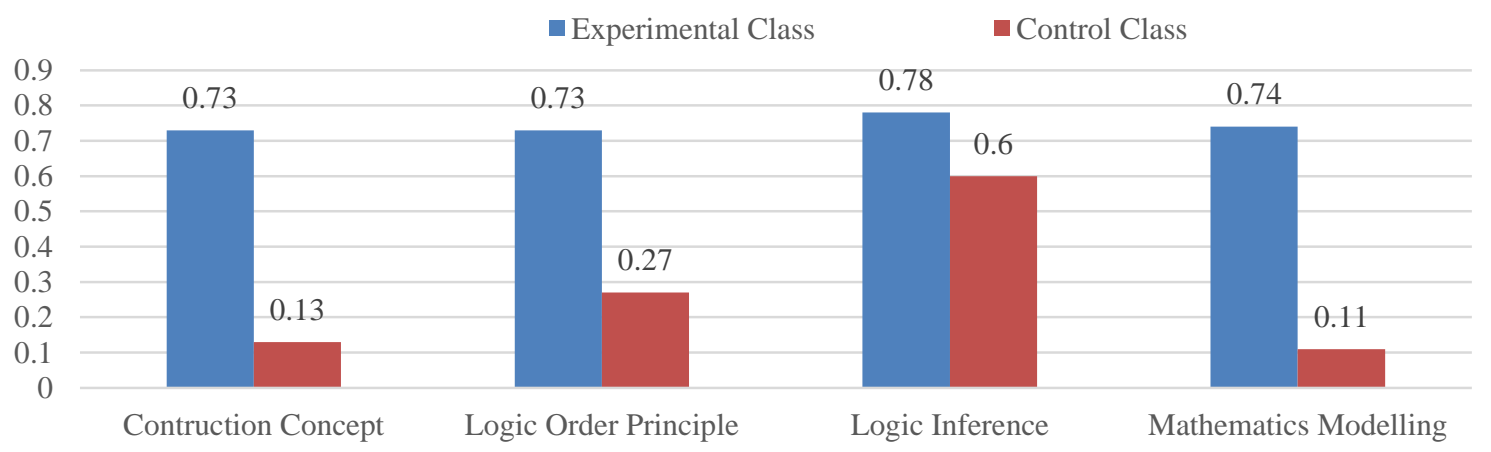

Figure 3. N-gain aspect of experiment and control Class

Figure 3 showed that generic science skill in the experiment class was higher than the control class on concept construction, basic logic principle, logic inference, and mathematics modeling aspect. Guided inquiry scientific method generally improves the students' generic science skill because, in this phase, the students were allowed to experiment with the main learning problem which was given by the lecturer.

In the phases of gaining data, the students were helped by video tracker analysis software that can provide quantitative data, simultaneous charts, and graphics from movement phenomena in the real life for instance car movement on straight track was a tool model that could help students, vertical ball movement and ball movement on parabola track. Video tracker analysis was a model tool to help students for understanding physics principles and improve students' abstraction and projection skills [17], encouraging students to think critically to understand physics concepts [2]. The use of video in the learning process could facilitate the inquiry process to understand physics' concepts through scientific procedures, interesting and enjoying learning [9]. Therefore, the application of guided inquiry scientific method analysis video tracker based on learning process was effective to improve students' generic science skills.

\section{CONCLUSIONS}

Based on the result of the study, it could be concluded that there was significant improvement of students' generic science inquiry skills after the application of guided inquiry method video tracker analysis based on conventional method. There was also improvement of students' generic science skills on aspects of concept construction, logic order principles, logic inference, and mathematics model. 


\section{International Journal of Current Science Research and Review}

ISSN: 2581-8341

Volume 04 Issue 12 December 2021

DOI: 10.47191/ijcsrr/V4-i12-12, Impact Factor: 5.825

IJCSRR@ 2021

Www.ijjcsrr.org

\section{REFERENCES}

1. C. Sirisathitkul, P. Glawtanong, T. Eadkong, and Y. Sirisathitkul, "Digital video analysis of falling objects in air and liquid using tracker," Rev. Bras. Ensino Fis., vol. 35, no. 1, pp. 1-6, 2013, doi: 10.1590/s1806-11172013000100020.

2. R. Rivera, "Learning Physics with Video Analysis," Nuevas Ideas en Informática Educ. TISE, pp. 121-125, 2013, [Online]. Available: http://www.tise.cl/volumen9/TISE2013/121-125.pdf.

3. M. G. Afifah, D. N., Yulianti, D., Agustina, N., Sri Lestari, R. D., \& Nugraha, "Metode Sederhana Menentukan Percepatan Gravitasi Bumi Menggunakan Aplikasi Tracker Pada Gerak Parabola Sebagai Media dalam Pembelajaran Fisika.," Pros. Simp. Nas. dan Pembelajaran Sains, vol. 2015, no. Snips, pp. 304-305, 2015.

4. J. A. Bryan, "Investigating the conservation of mechanical energy using video analysis: Four cases," Phys. Educ., vol. 45, no. 1, pp. 50-57, 2010, doi: 10.1088/0031-9120/45/1/005.

5. D. E. S. I. Asbanu, “Analisis Karakteristik Getaran Harmonik Sederhana dan Getaran Teredam Lemah Dengan Metode Analisis Video dan Logger Pro $\square$, , pp. 33-39, 2016.

6. J. Bonato, L. M. Gratton, P. Onorato, and S. Oss, "Using high speed smartphone cameras and video analysis techniques to teach mechanical wave physics," Phys. Educ., vol. 52, no. 4, 2017, doi: 10.1088/1361-6552/aa6f8c.

7. S. A. Fahrunnisa, Y. Rismawati, P. Sinaga, and D. Rusdiana, "Experiments of the law of conservation of mechanical energy using video tracker in high school learning," J. Phys. Conf. Ser., vol. 1806, no. 1, 2021, doi: 10.1088/17426596/1806/1/012035.

8. V. L. B. de Jesus and D. G. G. Sasaki, “A Simple Experiment to Determine the Moments of Inertia of the Fidget Spinner by Video Analysis,” Phys. Teach., vol. 56, no. 9, pp. 639-642, 2018, doi: 10.1119/1.5080587.

9. Z. Ješková, M. Kireš, M. Ganajová, and K. Kimáková, "Inquiry-based learning in science enhanced by digital technologies," ICETA 2011 - 9th IEEE Int. Conf. Emerg. eLearning Technol. Appl. Proc., pp. 115-118, 2011, doi: 10.1109/ICETA.2011.6112597.

10. S. Handajani, H. Pratiwi, and M. Mardiyana, "The 21 st century skills with model eliciting activities on linear program," $J$. Phys. Conf. Ser., vol. 1008, no. 1, 2018, doi: 10.1088/1742-6596/1008/1/012059.

11. P. W. Sanggara, A. Doyan, and N. N. S. P. Verawati, "the Effect of Process Oriented Guided Inquiry Learning Model Based on Virtual Laboraory Toward Problem Solving Abilities of Physics Student," J. Penelit. Pendidik. IPA, vol. 5, no. 1, pp. 1-5, 2018, doi: 10.29303/jppipa.v5i1.154.

12. T. Afriani, R. R. Agustin, and E. Eliyawati, "The Effect of Guided Inquiry Laboratory Activity with Video Embedded on Students' Understanding and Motivation in Learning Light and Optics,” J. Sci. Learn., vol. 2, no. 3, pp. 79-84, 2019, doi: 10.17509/jsl.v2i3.15144.

13. M. T. Sakliressy, W. Sunarno, and F. Nurosyid, "The Generic Science Skill Profile of High School on Theory Momentum and Impulse," J. Phys. Conf. Ser., vol. 1842, no. 1, 2021, doi: 10.1088/1742-6596/1842/1/012058.

14. P. D. S. M. S. D. S. H. M.Si, “The Ability of Generic Science at Observation and Inference Logic Prospective Chemistry Teacher in Organic Chemistry Experiment," Int. J. Sci. Res., vol. 4, no. 5, pp. 2975-2980, 2015, [Online]. Available: https://www.ijsr.net/archive/v4i5/SUB154947.pdf.

15. N. Khoiri, C. Huda, A. Rusilowati, Wiyanto, Sulhadi, and A. G. C. Wicaksono, "The impact of guided inquiry learning with digital swing model on students' generic science skill,” J. Pendidik. IPA Indones., vol. 9, no. 4, pp. 554-560, 2020, DOI: 10.15294/jpii.v9i4.26644.

16. J. W. Creswell, Research Design Pendekatan Kualitatif, Kuantitatif, dan Mixed Method, 3rd ed. Yogyakarta, 2013.

17. P. Hockicko, "Attractiveness of learning physics by means of video analysis and modeling tools," Proc. 40th SEFI Annu. Conf. 2012 - Eng. Educ. 2020 Meet Futur., no. September, 2012.

Cite this Article: Dens E. S. I. Asbanu (2021). Application of Scientific Guided Inquiry Assisted Video Analysis Tracker to Improve Science Generic Skills. International Journal of Current Science Research and Review, 4(12), 1693-1696 